\title{
Contributors / Contributeurs
}


Pierre Anctil is a member of the Royal Society of Canada and a full professor at the department of history of the University of Ottawa, where he teaches contemporary Canadian history and Canadian Jewish history. He has written at length on the history of the Jewish community of Montréal and on the current debates on cultural pluralism in Québec. He is the author of a literary biography of Montreal Yiddish poet Jacob-Isaac Segal, entitled Jacob-Isaac Segal (I896-I954), un poète yiddish de Montréal et son milieu (Presses de l'Université Laval, 2or2). He recently published a study of anti-Semitism in the Montréal daily Le Devoir entitled: 'À chacun ses Juifs.' 60 éditoriaux pour comprendre la position du Devoir à l'égard des Juifs I9IO-I947 (Septentrion, 20I4). His latest publication is: Les Juifs de Québec, 400 ans d'histoire (Presses de l'Université du Québec, 2015).

Katherine Biggs-Craft has been the curator of the Saint John Jewish Historical Museum since 1998. She holds degrees in History from the University of New Brunswick.

Antoine Burgard is a $\mathrm{PhD}$ candidate in History at Université Lumière Lyon 2 (France) and Université du Québec à Montréal (Canada), co-advised by Yolande Cohen and Isabelle von Bueltzingsloewen. Recipient of the Fondation Auschwitz Bourse de recherche 2012 and of the Institute for Canadian Jewish Studies (Concordia University) Yaacov Zipper Award 2014, he is a 2015-2016 fellow of the Fondation pour la Mémoire de la Shoah (FMS). He has been published in Bulletin d'Histoire Politique and Globe. Études Québécoises.

Melissa Caza has been an archivist at the Ontario Jewish Archives, Blankenstein Family Heritage Centre since 20Io. She holds an Honours BA in History from the University of Waterloo, and both a BEd and a MISt from the University of Toronto.

Jason Chalmers is a $\mathrm{PhD}$ candidate in the Department of Sociology at the University of Alberta. His research focuses on the relationship between genocide, settler colonialism, and public commemoration. Jason's dissertation explores how genocide narratives reproduce and resist national mythology, and focuses on three sites of $\mathrm{Ca}$ nadian memory: the National Holocaust Monument, the Truth and Reconciliation Commission, and the Canadian Museum for Human Rights.

Justin Comartin is currently an elementary school teacher with the Conseil scolaire catholique Providence (CSC Providence). He was the recipient of the Jacob Freedman Memorial Award from the Ottawa Jewish Historical Society in 2009 and received the Gaston Héon Graduate Scholarship in History from the University of Ottawa in 2012. He completed his MA thesis entitled Humanitarian Ambitions - International Barriers: Canadian Governmental Response to the Plight of the Jewish Refugees (1933-1945) in 2013. His areas of interest include: Canadian Immigration History, Commemoration and Memory, and Canadian participation in the World Wars. 
Norman Erwin earned his PhD in history from the University of Waterloo and specializes in the Holocaust's impact on Canadian Jewish political discourse. His current research focuses on North American Jewish responses to the rise of Arab nationalism during the Cold War.

Simon-Pierre Lacasse complète une maitrise en histoire à l'Université d'Ottawa vers l'été 2016 sous la direction de Pierre Anctil. Sa thèse se penche sur le parcours d'un groupe hassidique de la région montréalaise - les Tasher - alors qu'ils intègrent le Québec durant la période subséquente à la Deuxième Guerre mondiale. Il s'intéresse particulièrement aux rapports entre les communautés hassidiques, la plus grande communauté juive et la collectivité francophone du Québec dans leur dimension historique. Il s'engage actuellement dans des études doctorales à l'Université d'Ottawa.

Rebecca Margolis is associate professor in the University of Ottawa's Vered Jewish Canadian Studies Program. Her research interests deal with the transmission of Yiddish language and culture before and after the Holocaust. She is the author of Jewish Roots, Canadian Soil: Yiddish Culture in Montreal, 1905-1945 (McGill-Queen's University Press, 20II).

Lillooet Nördlinger McDonnell is a historian and writer and lives in Brooklyn, NY. She is specialized in Jewish integration, assimilation, and fringe Jewish communities.

Janice Rosen has been the Archives Director since 1989 of the Alex Dworkin Canadian Jewish Archives, formerly known as the Canadian Jewish Congress CC National Archives. Her publications include various surveys of Canadian Jewish archival resources and repositories for the Canadian Jewish Studies Journal. She is a co-creator of the Canadian Jewish Heritage Network, a database-driven website showcasing the holdings of several partner Archives and Museums.

Sheena Trimble, docteure en histoire contemporaine, a soutenu sa thèse à l'Université d'Angers, France, en octobre 2015 : « Femmes et politiques d'immigration au Canada (1945-1967) : au-delà des assignations de genre ». Ses recherches portent sur l'influence que les actions de femmes, conçues ou perçues comme politiques ou non, peuvent avoir sur les politiques de l'immigration. 